\title{
Caves of the Low Tatras National Park and Its Neighbourhood as Objects of Speleotourism
}

\section{Vladimír ČECH ${ }^{1}$, Bohuslava GREGOROVÁ ${ }^{2}$, Pavel HRONČEK ${ }^{2 *}$ and Anton FOGA $\check{S}^{1}$}

\author{
Authors' affiliations and addresses: \\ ${ }^{1}$ Department of Geography and Applied \\ Geoinformatics, Faculty of Humanities and \\ Natural Sciences, University of Prešov, Ulica 17. \\ November 1, 08116 Prešov, Slovakia, \\ e-mail: cech@unipo.sk, fogas@unipo.sk \\ ${ }^{2}$ Department of Geography and Geology, Faculty \\ of Natural Sciences, Matej Bel University, \\ Tajovského 40, 97401 Banská Bystrica, \\ Slovakia, \\ e-mail: bohuslava.gregorová@umb.sk, \\ pavel.hroncek@umb.sk

\section{*Correspondence:} \\ Pavel Hronček, Department of Geography and \\ Geology, Faculty of Natural Sciences, Matej Bel \\ University, Tajovského 40, 97401 Banská \\ Bystrica, Slovakia \\ tel.: +421484467304 \\ e-mail: pavel.hroncek@umb.sk \\ Funding information: \\ Slovak Research and Development agency \\ APVV-18-0185 "Land-use changes of Slovak \\ cultural landscape and prediction of its further \\ development". \\ How to cite this article: \\ Čech, V., Gregorová, B., Hronček, P. and Fogaš, \\ A. (2021). Caves of the Low Tatras National Park \\ and its Neighbourhood as Objects of \\ Speleotourism. Acta Montanistica Slovaca, \\ Volume 26 (2), 375-393 \\ DOI: \\ https://doi.org/10.46544/AMS.v26i2.15
}

\begin{abstract}
Publicly accessible caves are important objects of the modern form of tourism, which is called speleotourism. The caves are important underground geolocalities, which are characterized by a high accumulation of visitors in a specific natural environment. They are usually part of large protected areas - national parks and protected landscape areas. The study deals with accessible caves in the Low Tatras National Park in the central part of Slovakia. In the national park, or rather in its vicinity, there are four caves formed in the carbonate rocks of the geological core of the Low Tatras mountains. In the first part of the study, we presented their basic geographical characteristics in terms of their description as underground geolocalities. The main aim of the study is to analyze the number of visitors to the Demänovská Cave of Freedom, Demänovská Ice Cave, located directly in the national park, Bystrianska Cave located in the buffer zone of the national park and Važecká Cave, located on the northern edge of the studied area. Individual geolocalities were evaluated in terms of 12 criteria (e.g., Variety and attractiveness of cave decoration, Interpretation of the guide, Difficulty of the tour, Amount of ticket price, and others), which were indexed answers of (speleo)tourists from the opinion poll. We conducted the survey during the summer months in the period from 2010 to 2019, and a total of 160 respondents participated. The basic results of a standardized public opinion survey gave us the answer to five research hypotheses. The results confirmed the important potential of caves as specific geolocalities for the development of (underground) speleotourism as a modern form of tourism. Speleotourism is currently an important form of tourism, which is developing in the national parks.
\end{abstract}

\section{Keywords}

cave, geosite, speleotourism, caves attendance, evaluation, Low Tatras National Park 


\section{Introduction}

Caves are objects of geotourism, often sought after by visitors for a specific natural environment. In caves open to the public, it is mainly a cognitive form of tourism, focused on exploring the underground geosystem with various forms of cave filling, with a specific microclimate, hydrology, and fauna. The use of cave spaces for people with upper respiratory tract diseases as part of so-called speleotherapy is also linked to a specific cave's microclimate. Some cave spaces are rarely used for cultural purposes, such as cultural events, weddings, concerts, religious events, filming. They are also used as storage spaces, underground factories, respectively, somewhere they still have a residential function. The caves could be used for the preparation, training, and related activities of the armed forces for civil protection purposes, fire and rescue service members, the mountain rescue service, or the components of the integrated rescue system. Another form of use of cave spaces (even those inaccessible to the public) is scientific research associated with the efforts of speleologists to extend existing (known) cave systems and discover new ones.

In connection with the caves and their visit, the concept of speleotourism is well known. It is understood as a specific form of geotourism. Zelenka, Pásková (2012) understand speleotourism as a form of tourism associated with exploration and discovery of cave spaces and abysses. It usually includes climbing activities (abseiling, climbing ascents), cave diving, boat trips on underground rivers with guides. According to Panoš (2001), speleotourism is an organized speleological activity focused on cultural and cognitive activities in inaccessible endokarst objects (caves, abysses, and others), available to those possessing essential equipment (helmet, own lighting) and under the guidance of an experienced professional guide (speleologist - conservationist). These definitions are examples of a narrower understanding of the term speleotourism. Speleotourism, in a broader sense, is understood as an individual or group tourism organized in the commercial interest in caves accessible to the public or other attractive karst objects equipped with security features. These objects are illuminated, have marked paths, stairs, locked entrances; some have electric lifts. They are technically secured, and a trained guide carries out the tour.

The issue of speleotourism, respectively the use of caves and karst phenomenon in geotourism, is elaborated in the works of several authors. The general characteristics of speleotourism are analyzed in the works: Cardozo Moreira and Neto de Carvalho (2013), Cigna and Burri (2000), Cigna and Forti (2013), Doorne (2000), Kranjc (2008), and others. Regional aspects of speleotourism have been addressed by, e.g., Anderson (2010), Antic (2018), Cigna (1993), Emeka et al. (2017), Figueiredo (1998), Forti and Cigna (1989), Knežević and GrbacŽiković (2011), Lobo (2007), Lobo and Moretti (2009), Pavlovich (2003), Tičar et al. (2018), Tomic et al. (2018), Ulloa and Goicoechea (2013), Ruban (2018), Vuković and Antić (2019), Antić and Tomić (2019) and others.

Based on the study of these works, we understand and define speleotourism as a specific form of tourism. The participants' motive is to get to know and visit naturally created underground localities (caves, abysses, and other karst and non-karst underground forms) officially accessible by legislation. Visitors are usually equipped with basic infrastructure (lighting, modified paths), and guide activities are provided by a professionally trained person (guide). In specific cases, a visit to hard-to-reach underground speleological sites requires equipment (helmet, lighting) and accompaniment by speleologists, as these sites are not accessible to the public. In this case, speleotourism has elements of adrenaline tourism.

The karst areas of Slovakia occupy approximately 5.5\% of the entire area, with more than 7,000 registered caves. According to Act No. 543/2002 Coll. on Nature and Landscape Protection, a cave is understood as a hollow underground space in the earth's crust accessible to man and created by natural processes, the length or depth of which exceeds 2 meters and the dimensions of the surface hole are less than its length or depth. Overall, 18 caves are open to the public. Thirteen of them (Driny Cave, Harmanecká Cave, Brestovská Cave, Demänovská Cave of Liberty, Demänovská Ice Cave, Bystrianska Cave, Važecká Cave, Belianska Cave, Dobšinská Ice Cave, Ochtinská Aragonite Cave, Gombasecká Cave, Domica Cave, Jasovská Cave) are operated by the Slovak Caves Administration with its seat in Liptovský Mikuláš, which is a contributory organization of the State Nature Conservancy of the Slovak Republic. Five caves (Malá Stanišovská Cave, Dead Bats' Cave, Krásnohorská Cave, Zlá diera Cave (Evil Hole) and Bojnice Castle Cave) are operated by other entities.

A large portion of the registered caves in Slovakia is part of large protected areas - national parks or protected landscape areas. Of the nine national parks in Slovakia, the most publicly accessible caves (5) are located in the Low Tatras National Park. These are the Demänovská Cave of Liberty, the Demänovská Ice Cave, and the Bystrianska Cave. The Slovak Caves Administration in Liptovský Mikuláš operates these classically accessible caves. Two caves - Malá Stanišovská Cave and Dead Bats' Cave-are private entities and accessible to the public by a guide speleological service. All of the mentioned caves are significant objects of speleotourism in the Low Tatras National Park; they contribute to the attendance increase and thus represent the areas with the most significant accumulation of visitors within the Low Tatras National Park borders.

The main goal of the presented paper is to analyze the attendance of accessible caves of the Low Tatras National Park and its surroundings in the summer months for the period from 2010 to 2019, as well as to evaluate the potential of these caves for the development of speleotourism based on the results of carried out public opinion 
survey. We analyzed the attendance and conducted a public opinion survey in four caves. Two of them are located within the territory of the national park: Demänovská Cave of Liberty and Demänovská Ice Cave. The Bystrianska Cave is located in Horehronské podolie (Upper Hron River Basin) within the national park protection zone. The fourth is the Važecká Cave, which lies at the junction of Kozie chrbty Mountains and Liptovská kotlina Basin, about 1000 meters beyond the Low Tatras National Park protection zone border. We did not include the Dead Bats' Cave and Malá Stanišovská Cave in the research because there were no attendance data available for 20102019. Using the knowledge from previous research in this area, evaluation of the development and changes in the number of visitors to individual caves, we will look for answers to the following research hypotheses:

1. We assume a continuous annual increase in attendance for all four caves due to the continuous increase in attendance in the national park.

2. We assume that the highest number of visitors is in the Demänovská Cave of Liberty and the Demänovská Ice Cave, due to the intense pressure of tourism in the Demänovská Valley both during winter and summer.

3. We assume that the lowest number of visitors is in the Važecká Cave due to its marginal location concerning the Low Tatras' main tourism centers (South and North Chopok).

4. We assume that the guide's approach in the cave and its interpretation is essential in evaluating the cave in terms of its attractiveness, respectively, the potential for speleotourism.

5. We assume that the Demänovská Cave of Liberty has the most significant potential for speleotourism.

\section{Materials and Methods}

\section{Study sites}

The studied geolocations are part of the Low Tatras National Park, except for one locality (Važecká Cave), which lies near the protection zone borders (Figure 1). The national park was declared by the Government Regulation of the Slovak Socialist Republic No. 119/1978 of June 14, 1978. By the Government Regulation of the Slovak Republic No. 182/1997 Coll. of June 17, 1997, the national park boundaries and protection zone were modified and amended. The administration seat is in Banská Bystrica, and the national park territory has 72,842 ha, the protection zone has 110,162 ha. The Low Tatras represent a significant mountain barrier, located approximately in the middle of central Slovakia. The National Park, together with its protection zone administratively extends into the Žilina Region, the Banská Bystrica Region and the Prešov Region, into five districts: Ružomberok, Liptovský Mikuláš, Poprad, Brezno and Banská Bystrica and into the cadastral territories of 88 municipalities. The national park with a protection zone covers almost the entire Low Tatras and most Starohorské vrchy Mts. It extends marginally to the Kozie chrbty Mt., Liptovská kotlina Basin, the Spiš-Gemer Karst and Horehronské podolie (the Upper Hron River Basin). In the west, it borders the National Park of Vel'ká Fatra, in the east and the southeast with the Slovak Paradise National Park and the National Park of Muránska planina.

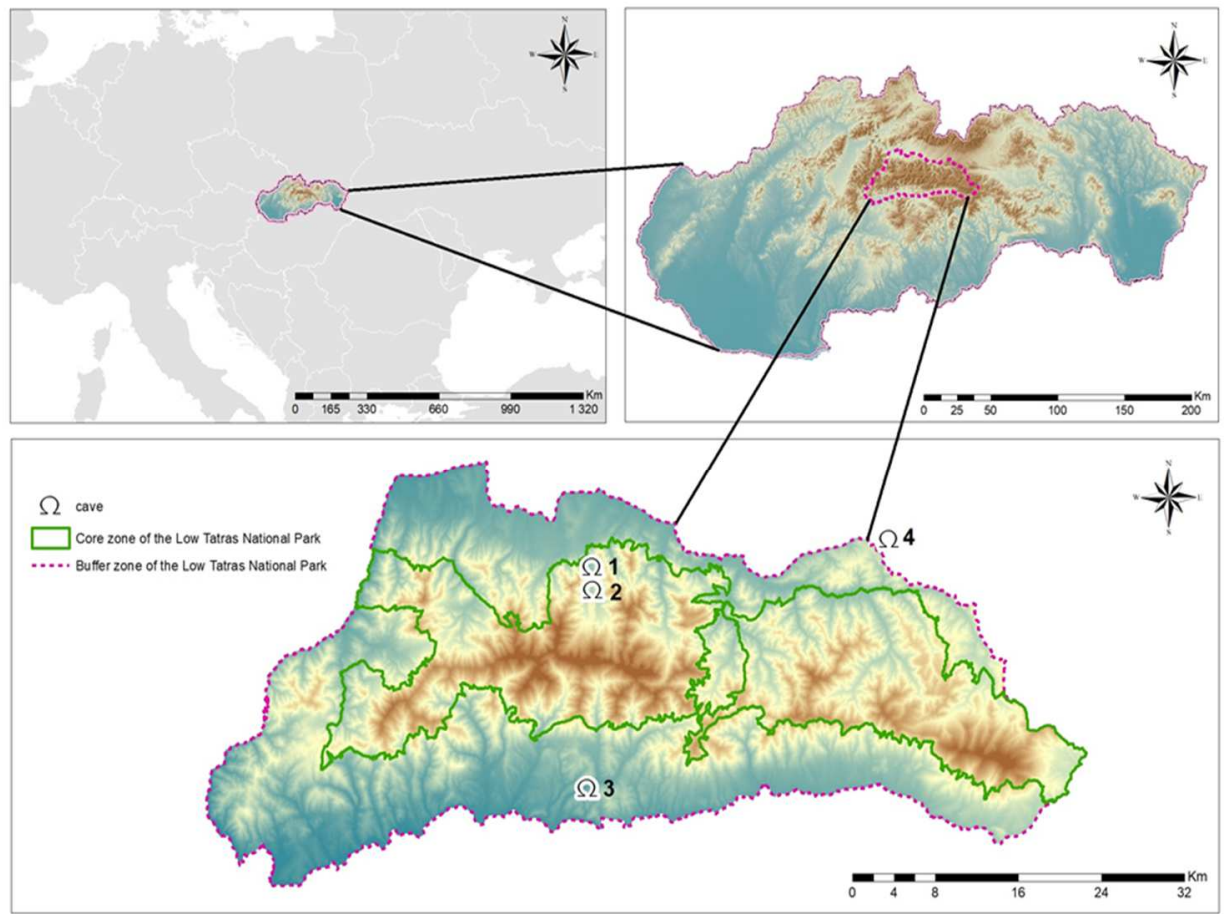

Fig. 1. Location of study sites: 1 - Demänovská Ice Cave, 2 - Demänovská Cave of Liberty, 3 - Bystrianska Cave, 4 - Važecká Cave 
According to the regionalization of Hochmuth (2008), the karst areas in which these localities lie belong to the following units: Karst of Demänovská Valley (Demänovská Cave of Liberty and Demänovská Ice Cave), Bystriansko-valašský Karst (Bystrianska Cave) and Važecký Karst (Važecká Cave). The basic parameters of the caves are listed in Table 1.

Demänovská Ice Cave - It is located on the right side of the Demänovská Valley on the northern side of the Low Tatras. It is located in the Demänovská Valley National Nature Reserve in the Low Tatras National Park. The entrance to the cave in the Bašta hill is at an altitude of $840 \mathrm{~m}$ a. s. 1., about $90 \mathrm{~m}$ above the bottom of the valley. The ascent to the cave takes about 20 minutes. The tour circuit is $650 \mathrm{~m}$ long and $48 \mathrm{~m}$ high, but visitors will pass $800 \mathrm{~m}$ in the cave; the total number of stairs is 670 . The entrance and exit are at the same altitude; the distance between them is only $40 \mathrm{~m}$. The stay in the cave lasts about 45 minutes. The temperature in the cave during the summer months varies from $+0.4{ }^{\circ} \mathrm{C}$ to $+3{ }^{\circ} \mathrm{C}$. The cave is open to the public from May 15 to September 30 , and entrances are in the main (summer) season from 9.00 to 16.00 every full hour. The ticket price for an adult is 8 euros (2019). In 2019, the cave was visited by 71,262 tourists. It is formed in the Middle Triassic dark gray Gutenstein limestones of the Křížňany mantle along tectonic faults by the former Demänovka submerged stream, which flowed from the Demänovská Cave of Peace. It represents the northern, former spring part of the Demänovské cave system, the most extended cave system in Slovakia with more than $41 \mathrm{~km}$ of underground spaces. Some of the cave's upper parts are formed by the waters of the side submersible arm of Demänovka, and the length of the targeted parts of the cave is $2,445 \mathrm{~m}$ with a height difference of $57 \mathrm{~m}$. The cave spaces in the three development levels consist of oval, river-shaped corridors with ceiling and side troughs (Black Gallery, Jazerná chodba, Medvedia chodba) and dome-shaped spaces completed by rushing and frost weathering (Pebble Dome, Great Dome, Kmet'ov Dóm, Belov dome, Dome of the Ruins). Ice filling occurs in the lower parts of the cave, especially in the Kmetov dome. Floor ice, ice columns, stalactites, and stalagmites are represented. Conditions for glazing occurred after filling the surface openings with slope processes, which limited the air exchange. Heavier cold air is maintained in the lower parts of the cave. Leaking rainwater freezes in cold underground spaces. The air temperature in the icy parts is around $0{ }^{\circ} \mathrm{C}$, rising to 1.3 to $5.7{ }^{\circ} \mathrm{C}$ for the non-icy parts. The relative humidity is 92 to $98 \%$. However, the ice decoration has been significantly reduced, especially in recent years, and in some years, only floor ice is represented. It is said that the Demänovská Ice Cave has been known since time immemorial. The first mention of openings to caves in the Demänovská valley is in the Esztergom Chapter from 1299. However, it cannot be applied to a specific cave. The first written mention of the Demänovská Ice Cave refers to the description of the cave near Liptovský Mikuláš from 1672 by J. P. Hain, who was interested in cave bear bones and considered them to be the bones of dragons. Further mention of the Demänovská Ice Cave is related to G. Buchholtz Jr., who examined its premises in 1719. Together with a cave drawing, their description was sent to M. Bel, who published these data in 1723. The initial tourist access to the cave took place in the middle of the 19th century. The cave was reopened between 1950 and 1952, including electric lighting (Bella 2011, Bella et al. 2014, Droppa 1957a, 1959, 1972).

Demänovská Cave of Liberty - located on the right side of the Demänovská Valley on the northern side of the Low Tatras, in the Demänovská Valley National Nature Reserve in the Low Tatras National Park. The entrance to the cave in the Točište valley is at $870 \mathrm{~m}$ a.s.1. The serpentine path from the parking lot to the cave is about 400 $\mathrm{m}$ long and $67 \mathrm{~m}$ high. The ascent to the cave takes $10-15 \mathrm{~min}$, and the cave offers two sightseeing tours. The traditional tour circuit is $1,150 \mathrm{~m}$ long, $86 \mathrm{~m}$ high, and has 913 steps. The tour lasts about 60 minutes. The extended circuit has $2,150 \mathrm{~m}$, the same elevation, 1,118 steps, and the tour takes 100 minutes. The cave is open to the public from January 2 to November 15; the entrances of the traditional circuit are in the main (summer) season from 9.00 to 16.00 every hour, the long circuit is realized once a day at 13.15. The ticket price for an adult on a traditional circuit is $9 €$ and $16 €$ on a long circuit (2019).

The cave was visited by 118,703 tourists in 2019 . The cave represents the most morphologically diverse part of the Demänovské cave system, the most extended cave system in Slovakia with more than $41 \mathrm{~km}$. It is formed in the Mesozoic dark gray Gutenstein limestones of the Křŕžňany mantle along tectonic faults by the Demänovka submerged stream and its lateral submerged tributaries. The length of the cave is $11,117 \mathrm{~m}$, with a height difference of $130 \mathrm{~m}$. The lower, river-modeled corridors represent several horizontal development levels (Marble River, Clay Corridor, Dry Corridor, Ground Floor, King's Gallery). In places, they are extended by routing (Great and Gargoyle Dome, Pink Hall, Hell's Dome). Steeply descending corridors lead to the cave levels in the suspended position, especially from the current entrance and exit from the cave.

The Miracle Halls, the Magic Corridor, and the Stone Vineyard have a fissure character without significant features of river modeling. The rich sinter filling is unique with sinter water lilies and other lake forms (spongy, coral, grape) and eccentric stalactites, forming substantial sinter waterfalls and stalagmites, spherulitic stalactites, and many other forms. The underground stream of Demänovka, which springs below the main ridge of the Low Tatras in the non-karst area and sinks underground in Lúčky, flows through the cave. It reaches the surface through the Vyvieranie cave north of the Demänovská Cave of Liberty. There are many lakes and ponds in the cave, the 
largest of them in inaccessible parts - the Great (Těsnohlídkove) lake is $52 \mathrm{~m} \mathrm{long}, 5$ to $12 \mathrm{~m}$ wide, and more than $7 \mathrm{~m}$ deep. The air temperature in the cave system is 6.1 to $7.0^{\circ} \mathrm{C}$, and the relative humidity is 94 to $99 \%$. The cave was discovered by A. Král with the help of A. Mišura and other explorers through the dry lowest dive of Demänovka in 1921 and named it Temple of Liberty. The Commission for the Publication of Demänovské Caves, which began access work, was established in 1922. In 1923, they installed temporary electric lighting. Part of the cave from the Marble River through the Great Dome to the Golden Lake was opened in 1924 (Bella 2011, Bella et al. 2014, Droppa 1957a, 1959, 1972).

Bystrianska Cave is located in the submerged zone of the Bvstriansko-valašský Karst in the Bystrianské podhorie of the Horehronské podolie Basin, on the southern edge of the village Bystrá near the recreation center Tále on the southern side of the Low Tatras. The entrance to the cave at the foot of the northwestern slope of Chodorový vrch is at $565 \mathrm{~m}$ a.s.l. and is about $120 \mathrm{~m}$ away from the parking lot with a minimum elevation gain. The tour circuit is $580 \mathrm{~m}$ long and is almost without elevation ( $26 \mathrm{steps}$ ). The tour lasts 45 minutes. The temperature in the cave is from 5.7 to $6.7^{\circ} \mathrm{C}$. The cave is open to the public from January 2 to October 31 ; entrances are in the main (summer) season from 9.00 to 16.00 every hour. The price of a ticket for an adult is 6 euros (2019). In 2019, the cave was visited by 28,984 tourists. It is formed in the Mesozoic dark gray limestones of the Choč mantle with corneal inserts. The positions of light-gray dolomites also alternate in them. Steep tectonic faults strongly determine the direction of the cave corridors. The cave reaches a length of more than $3,531 \mathrm{~m}$ and a vertical span of $99 \mathrm{~m}$. Depending on the deepening of the valley bottom, it was created in several developmental stages by the submerged waters of Bystrianka flowing into the karst area from the southern slopes of the Low Tatras. The oldest is a meandering river in the Old Cave, whose entrance is $70 \mathrm{~m}$ above the current stream Bystrianka. At present, the submerged watercourse flows through the lowest and youngest parts of the New Cave, which lie $14 \mathrm{~m}$ lower than the $160 \mathrm{~m}$ distant Bystrianka subway in front of the cave. The main areas of the New Cave are primarily narrow and high fissure corridors extended by corrosion and erosion of the watercourse. There are also larger atrial and dome-like spaces, mainly of a routine nature (Ruined Dome, Mostárenské Halls). The 70 m deep abyss Peklo flows into the lower parts of the New Cave. The sinter filling is dominated by curtains (Chapel), which in places hang from the edge of sinter crusts formed on former, later melted river sediments (Canopy). Aragonite occurs in places below Peklo. The air temperature is 5.7 to $6.7{ }^{\circ} \mathrm{C}$, and relative humidity is from 92 to $98 \%$. Locals have known about the opening to the Old Cave for a long time. J. Kovalčík and E. Laubert were the first to dare to enter the underground in 1923. In 1939 - 1940, the Bystrianske Caves Cooperative opened part of the cave without electric lighting. A memorial plaque commemorates the tragic event of the anti-fascist resistance from World War II in the Collapse Cathedral. The cave has been accessible in its current state since 1968. Since 1971, the Lower Partisan Hall has been used for speleotherapy (Droppa 1957b, Bella 1998, 2011).

Važecká Cave is located in the Važecký Karst at the junction of Kozie chrbty Mts. with the Liptovská kotlina Basin, on the western edge of the village of Važec. The cave entrance, located $8 \mathrm{~m}$ above the Biely Váh valley floodplain, lies $784 \mathrm{~m}$ a.s.l. The parking lot is located immediately in front of the cave entrance. The length of the tour route is 235 meters, with 5 m of elevation 5 meters and 88 steps. The duration of the tour is about 25 minutes. The cave temperature is from $6.5^{\circ} \mathrm{C}$ to $7.1{ }^{\circ} \mathrm{C}$. The cave is open to the public from February 1 to November 30 ; entrances are in the main (summer) season from 9.00 to 16.00 every hour, and the price of a ticket for an adult is $5 €$ (2019). The cave was visited by 19,109 tourists in 2019. It was created in the Mesozoic dark gray Gutenstein limestones of the Białowieża series of the Choč mantle by the former immersion waters of the sidearm of the White Váh. It reaches a length of $530 \mathrm{~m}$. In several places, the original river-modeled corridors are altered by routing, especially along with the interlayer areas of limestone. The underground spaces are decorated mainly with stalactites, stalagmites, and sinter lakes. A large part of the cave is filled with fine sediments washed away by the former, especially floodwaters of Biely Váh. The air temperature is 6.5 to $7.1{ }^{\circ} \mathrm{C}$, and the relative humidity is from 94 to $96 \%$. The cave entrance parts are affected by climate changes on the surface during the year, manifested in winter by frost weathering of limestones. The entrance hall was long known to the locals. The continuation of the cave spaces was discovered in 1922 by O. A. Húska with the collaboration of A. Some. According to F. Havránek, who leased the cave from the Važecký land register in 1922, it was provisionally opened in 1928. After the reconstruction of the tour sidewalk and the installation of electric lighting, the cave has been in operation since 1954 (Droppa 1962a, 1962b, Bella 2011).

\begin{tabular}{|c|c|c|c|c|}
\hline \multicolumn{1}{|c|}{ Tab. 1. Basic parameters of the studied caves } \\
\hline $\begin{array}{c}\text { Demänovská } \\
\text { Ice Cave }\end{array}$ & $\begin{array}{c}\text { Demänovská } \\
\text { Cave of } \\
\text { Liberty }\end{array}$ & $\begin{array}{c}\text { Bystrianska } \\
\text { Cave }\end{array}$ & $\begin{array}{c}\text { Važecká } \\
\text { Cave }\end{array}$ \\
\hline $\begin{array}{c}\text { Altitude of the entrance in metres } \\
\text { above sea level }\end{array}$ & 840 & 870 & 1 & 784 \\
\hline $\begin{array}{c}\text { Ascent to the cave from the parking lot } \\
\text { in minutes }\end{array}$ & 20 & 15 & 3531 & 0 \\
\hline Total length of the cave in metres & 2445 & 11117 & 530 \\
\hline
\end{tabular}




\begin{tabular}{|c|c|c|c|c|}
\hline Length of the tour in metres & 650 & $\begin{array}{c}1150 \\
\text { (traditional } \\
\text { tour) } \\
2150 \text { (long } \\
\text { tour) }\end{array}$ & 580 & 235 \\
\hline Elevation on the tour in metres & 48 & 86 (both tours) & 0 & 5 \\
\hline Number of stairs on the tour & 670 & $\begin{array}{c}913 \text { (traditional } \\
\text { tour) } \\
1118 \text { (long } \\
\text { tour) }\end{array}$ & 26 & 88 \\
\hline Duration of the tour in minutes & 45 & $\begin{array}{c}60 \text { (traditional } \\
\text { tour) } \\
100 \text { (long tour) }\end{array}$ & 45 & 25 \\
\hline $\begin{array}{l}\text { Ticket price for an adult in } € \text { (year } \\
\qquad 2019 \text { ) }\end{array}$ & 8 & $\begin{array}{c}9 \text { (tradition } \\
\text { tour) } \\
16 \text { (long tour) }\end{array}$ & 6 & 5 \\
\hline
\end{tabular}

Source: own research

\section{Analysis of attendance and public opinion survey}

In the analysis of attendance, we processed data provided from the Slovak Caves Administration for ten years (2010-2019), as we consider this period to be sufficiently long to analyze trends in their attendance. Due to the different opening hours of the studied caves, we focused on the period of the primary tourist season (June-August), when all four caves are open to the public.

For this paper, a public opinion survey was prepared in terms of the general methodology for creating a questionnaire (Taylor-Powell 1998; Švec 1998). The survey consisted of 12 questions with a predetermined range of possible answers. Decisive criteria were selected to evaluate the potential of caves for speleotourism, and the respondents determined the order of significance of individual criteria (classification indices) (Table 2). Determination of the degree of significance of the leading classification indices and calculating their standardized weight (Tables 3-14) was processed according to Ř́ha's methodology (1995a, b). Within each classification index, the final value for the classification index was obtained, and the final point value of the cave potential (K) for speleotourism was also calculated (Table 16) based on the formula:

$\mathrm{K}=\sum_{i=1}^{3} K_{1 i} * W_{1}^{n}+\sum_{i=1}^{4} K_{2 i} * W_{2}^{n}+\sum_{i=1}^{3} K_{3 i} * W_{3}^{n}+\sum_{i=1}^{3} K_{4 i} * W_{4}^{n}+\sum_{i=1}^{3} K_{5 i} * W_{5}^{n}+\sum_{i=1}^{3} K_{6 i} * W_{6}^{n}+$ $\sum_{i=1}^{2} K_{7 i} * W_{7}^{n}+\sum_{i=1}^{3} K_{8 i} * W_{8}^{n}+\sum_{i=1}^{3} K_{9 i} * W_{9}^{n}+\sum_{i=1}^{3} K_{10 i} * W_{10}^{n}+\sum_{i=1}^{3} K_{11 i} * W_{11}^{n}+\sum_{i=1}^{3} K_{12 i} * W_{12}^{n}$

The respondents were 160 students of the Department of Geography and Applied Geoinformatics FHPV PU in Prešov (aged 18-20 years) who completed the tour in all localities as part of the field practices. Respondents were not informed in advance that they would take part in the public opinion survey, they filled it in immediately after completing the tour, and the teacher provided an additional expert interpretation for each object. Respondents agreed with the processing and publication of the survey results, which were then analyzed, recalculated, rounded to a percentage, and processed into a publication in a scientific journal.

Tab. 2. Order of significance of individual criteria and calculation of their importance value

\begin{tabular}{|l|c|c|c|c|}
\hline \multicolumn{1}{|c|}{ Classification index (criterion) } & $k_{r i}$ & $k_{r i}^{s}$ & $W_{j}$ & $W_{j}^{n}=W_{j} / y$ \\
\hline$k_{1 i}$ Variety and attractiveness of cave decoration & 1 & 1,5 & 11,5 & 0,128 \\
\hline$k_{2 i}$ Interpretation of the guide & 1 & 1,5 & 11,5 & 0,128 \\
\hline$k_{3 i}$ Difficulty of the tour & 2 & 4 & 10 & 0,111 \\
\hline$k_{4 i}$ Occurrence of groundwater and lakes & 2 & 4 & 10 & 0,111 \\
\hline $\begin{array}{l}k_{5 i} \text { Occurrence of other tourist destinations in the } \\
\text { neighbourhood of the cave }\end{array}$ & 2 & 4 & 10 & 0,111 \\
\hline $\begin{array}{l}k_{6 i} \text { Accessibility from the parking lot to the cave } \\
\text { entrance }\end{array}$ & 3 & 7,5 & 7,5 & 0,083 \\
\hline$k_{7 i}$ Amount of ticket price & 3 & 7,5 & 7,5 & 0,083 \\
\hline
\end{tabular}




\begin{tabular}{|l|c|c|c|c|}
\hline$k_{8 i}$ Illumination of cave's spaces & 3 & 7,5 & 7,5 & 0,083 \\
\hline$k_{9 i}$ Safety on the tour & 3 & 7,5 & 7,5 & 0,083 \\
\hline $\begin{array}{l}k_{10 i} \text { Transport accessibility in relation to major } \\
\text { transport routes }\end{array}$ & 4 & 10 & 4 & 0,044 \\
\hline $\begin{array}{l}k_{11 i} \text { Information panels about the cave and the } \\
\text { surrounding area }\end{array}$ & 5 & 11,5 & 1,5 & 0,017 \\
\hline$k_{12 i}$ Services provided at the entrance to the cave & 5 & 11,5 & 1,5 & 0,017 \\
\hline
\end{tabular}

Explanatory notes: $k_{r i}-$ simple order of significance, $k_{r i}^{S}-$ standardized order of index, $W_{j}$ - importance of index, $W_{j}^{n}-$ standard importance of indices, $\mathrm{y}=\left(\mathrm{W}_{1}+\mathrm{W}_{2}+\mathrm{W}_{3}+\ldots+\mathrm{W}_{12}\right)$

Tab. 3. Classification index: Variety and attractiveness of cave decoration

\begin{tabular}{|c|c|c|c|c|}
\hline Classification index $k_{1 i}$ & $k_{1 i}$ & $k_{1 i}^{s}$ & $k_{1 i}$ & $K_{1 i} * W_{1}^{n}$ \\
\hline $\begin{array}{c}\text { Rich occurrence of dripstone (or ice) decoration } \\
\text { along the entire tour }\end{array}$ & 1 & 1 & 3 & 0,384 \\
\hline $\begin{array}{c}\text { Sporadic occurrence of dripstone (or ice) } \\
\text { decoration in some corridors and halls }\end{array}$ & 2 & 2 & 2 & 0,256 \\
\hline $\begin{array}{c}\text { Low occurrence of decoration, predominance of } \\
\text { spaces without dripstone (or ice) decoration }\end{array}$ & 3 & 3 & 1 & 0,128 \\
\hline
\end{tabular}

Explanatory notes: $k_{1 i}-$ simple order of significance, $k_{1 i}^{s}-$ standardized order of index, $k_{1 i}-$ importance of index

Tab. 4. Classification index: Interpretation of the guide

\begin{tabular}{|c|c|c|c|c|}
\hline Classification index $k_{2 i}$ & $k_{2 i}$ & $k_{2 i}^{s}$ & $k_{2 i}$ & $K_{2 i} * W_{2}^{n}$ \\
\hline $\begin{array}{c}\text { Excellent, funny, with the opportunity to ask } \\
\text { questions }\end{array}$ & 1 & 1 & 4 & 0,512 \\
\hline Sufficient, with the opportunity to ask questions & 2 & 2 & 3 & 0,384 \\
\hline $\begin{array}{c}\text { Average, basic information without the } \\
\text { opportunity of asking additional questions }\end{array}$ & 3 & 3 & 2 & 0,256 \\
\hline Insufficient, little information & 4 & 4 & 1 & 0,128 \\
\hline
\end{tabular}

Tab. 5. Classification index: Difficulty of the tour

\begin{tabular}{|c|c|c|c|c|}
\hline Classification index $k_{3 i}$ & $k_{3 i}$ & $k_{3 i}^{s}$ & $k_{3 i}$ & $K_{3 i} * W_{3}^{n}$ \\
\hline Easy, without large elevations & 1 & 1 & 3 & 0,333 \\
\hline Quite difficult, sporadic occurrence of stairs & 2 & 2 & 2 & 0,222 \\
\hline $\begin{array}{c}\text { Difficult, higher elevation, frequent occurrence of } \\
\text { stairs }\end{array}$ & 3 & 3 & 1 & 0,111 \\
\hline
\end{tabular}


Tab. 6. Classification index: Occurrence of groundwater and lakes

\begin{tabular}{|c|c|c|c|c|}
\hline Classification index $k_{4 i}$ & $k_{4 i}$ & $k_{4 i}^{s}$ & $k_{4 i}$ & $K_{4 i} * W_{4}^{n}$ \\
\hline Occurrence of watercourses and lakes on the tour & 1 & 1 & 3 & 0,333 \\
\hline Occasional occurrence of lakes on the tour & 2 & 2 & 2 & 0,222 \\
\hline No watercourses and lakes on the tour & 3 & 3 & 1 & 0,111 \\
\hline
\end{tabular}

Tab. 7. Classification index: Occurrence of other tourist destinations in the neighborhood of the cave

\begin{tabular}{|c|c|c|c|c|}
\hline Classification index $k_{5 i}$ & $k_{5 i}$ & $k_{5 i}^{s}$ & $k_{5 i}$ & $K_{5 i} * W_{5}^{n}$ \\
\hline $\begin{array}{c}\text { Occurrence of other tourist destinations within a } \\
\text { distance of } 10 \mathrm{~km} \text { from the cave }\end{array}$ & 1 & 1 & 3 & 0,333 \\
\hline $\begin{array}{c}\text { Occurrence of other tourist destinations within a } \\
\text { distance of } 20 \mathrm{~km} \text { from the cave }\end{array}$ & 2 & 2 & 2 & 0,222 \\
\hline $\begin{array}{c}\text { Occurrence of other tourist destinations within a } \\
\text { distance of 50 km from the cave }\end{array}$ & 3 & 3 & 1 & 0,111 \\
\hline
\end{tabular}

Tab. 8. Classification index: Accessibility from the parking lot to the cave entrance

\begin{tabular}{|c|c|c|c|c|}
\hline Classification index $k_{6 i}$ & $k_{6 i}$ & $k_{6 i}^{s}$ & $k_{6 i}$ & $K_{6 i} * W_{6}^{n}$ \\
\hline Undemanding & 1 & 1 & 3 & 0,249 \\
\hline Average & 2 & 2 & 2 & 0,166 \\
\hline Demanding & 3 & 3 & 1 & 0,083 \\
\hline
\end{tabular}

Tab. 9. Classification index: Ticket price

\begin{tabular}{|c|c|c|c|c|}
\hline Classification index $k_{7 i}$ & $k_{7 i}$ & $k_{7 i}^{s}$ & $k_{7 i}$ & $K_{7 i} * W_{7}^{n}$ \\
\hline Adequate to the experience gained & 1 & 1 & 2 & 0,166 \\
\hline Inadequate to the experience gained & 2 & 2 & 1 & 0,083 \\
\hline
\end{tabular}

Tab. 10. Classification index: Illumination of cave's spaces

\begin{tabular}{|c|c|c|c|c|}
\hline Classification index $k_{8 i}$ & $k_{8 i}$ & $k_{8 i}^{s}$ & $k_{8 i}$ & $K_{8 i} * W_{8}^{n}$ \\
\hline $\begin{array}{c}\text { Adequate lighting, suitably complements the tour } \\
\text { of the cave }\end{array}$ & 1 & 1 & 3 & 0,249 \\
\hline
\end{tabular}




\begin{tabular}{|c|c|c|c|c|}
\hline $\begin{array}{c}\text { Medium lighting, in some areas a different } \\
\text { intensity would be appropriate }\end{array}$ & 2 & 2 & 2 & 0,166 \\
\hline Insufficient, low lighting & 3 & 3 & 1 & 0,083 \\
\hline
\end{tabular}

Tab. 11. Classification index: Safety on the tour

\begin{tabular}{|c|c|c|c|c|}
\hline Classification index $k_{9 i}$ & $k_{9 i}$ & $k_{9 i}^{s}$ & $k_{9 i}$ & $K_{9 i} * W_{9}^{n}$ \\
\hline $\begin{array}{c}\text { Sufficient safety, sufficient occurrence of safety } \\
\text { elements - stairs, railings, etc. }\end{array}$ & 1 & 1 & 3 & 0,249 \\
\hline $\begin{array}{c}\text { Average safety, in some areas it would be } \\
\text { appropriate to place more safety features }\end{array}$ & 2 & 2 & 2 & 0,166 \\
\hline $\begin{array}{c}\text { Insufficient safety, low occurrence of safety } \\
\text { elements }\end{array}$ & 3 & 3 & 1 & 0,083 \\
\hline
\end{tabular}

Tab. 12. Classification index: Transport accessibility in relation to major transport routes

\begin{tabular}{|c|c|c|c|c|}
\hline Classification index $k_{10 i}$ & $k_{10 i}$ & $k_{10 i}^{s}$ & $k_{10 i}$ & $K_{10 i} * W_{10}^{n}$ \\
\hline Good & 1 & 1 & 32 \\
\hline Average & 2 & 2 & 2 \\
\hline Bad & 3 & 3 & 0,088 \\
\hline
\end{tabular}

Tab. 13. Classification index: Information panels about the cave and the surrounding area

\begin{tabular}{|c|c|c|c|c|}
\hline Classification index $k_{11 i}$ & $k_{11 i}$ & $k_{11 i}^{s}$ & $k_{11 i}$ & $K_{11 i} * W_{11}^{n}$ \\
\hline Sufficient occurrence & 1 & 1 & 3 \\
\hline Average occurrence & 2 & 2 & 2 \\
\hline Unsufficient occurrence & 3 & 3 & 0,034 \\
\hline
\end{tabular}

Tab. 14. Classification index: Services provided at the entrance to the cave (souvenirs, toilets etc.)

\begin{tabular}{|c|c|c|c|c|}
\hline Classification index $k_{12 i}$ & $k_{12 i}$ & $k_{12 i}^{s}$ & $k_{12 i}$ & $K_{12 i} * W_{12}^{n}$ \\
\hline Sufficient level of services & 1 & 1 & 3 \\
\hline Average level of services & 2 & 2 & 2 \\
\hline Unsufficient level of services & 3 & 3 & 0,051 \\
\hline
\end{tabular}




\section{Results}

In terms of caves attendance, we focused on the summer months of 2010-2019, when all four caves are open to the public (Table 15, Graph 1-5). The above statistical data show that the most visited cave in the examined area of the Low Tatras National Park and the immediate vicinity is the Demänovská Cave of Liberty. The total attendance in the cave for the three summer months in 2010-2019 reached 647830 visitors. The number of visitors reached the highest values for 2010-2019 in August (275 479), the lowest in June (132 062). Most visitors came to the cave in 2016 when their number in 3 summer months reached 76 090, the least in 2010 (58 195).

Tab. 15. Caves attendance during the summer months for the period 2010-2019

\begin{tabular}{|c|c|c|c|c|c|c|c|c|c|c|c|}
\hline Cave & month & $\mathbf{2 0 1 0}$ & $\mathbf{2 0 1 1}$ & $\mathbf{2 0 1 2}$ & $\mathbf{2 0 1 3}$ & $\mathbf{2 0 1 4}$ & $\mathbf{2 0 1 5}$ & $\mathbf{2 0 1 6}$ & $\mathbf{2 0 1 7}$ & $\mathbf{2 0 1 8}$ & $\mathbf{2 0 1 9}$ \\
\hline \multirow{3}{*}{$\begin{array}{c}\text { Bystrianska } \\
\text { Cave }\end{array}$} & June & 3044 & 3313 & 2914 & 3125 & 2904 & 3363 & 4109 & 3794 & 4974 & 4146 \\
\cline { 2 - 13 } & July & 4769 & 4873 & 4772 & 4018 & 5167 & 5057 & 5720 & 5689 & 5989 & 6651 \\
\cline { 2 - 13 } & August & 4485 & 4411 & 5308 & 5037 & 5871 & 6212 & 5452 & 7359 & 7019 & 7024 \\
\hline $\begin{array}{c}\text { Demänovská } \\
\text { Cave of } \\
\text { Liberty }\end{array}$ & June & 13061 & 14845 & 11605 & 12234 & 11973 & 12483 & 14940 & 13573 & 14098 & 13250 \\
\cline { 2 - 13 } & July & 21457 & 24716 & 22018 & 21640 & 22540 & 21934 & 30022 & 25354 & 25145 & 25463 \\
\hline \multirow{2}{*}{$\begin{array}{c}\text { Demänovská } \\
\text { Ice Cave }\end{array}$} & August & 23677 & 23557 & 26222 & 27529 & 27179 & 27920 & 31128 & 30247 & 27831 & 30189 \\
\cline { 2 - 13 } & July & 22429 & 2583 & 23071 & 23946 & 23874 & 23678 & 28126 & 26502 & 26380 & 24525 \\
\hline & August & 25999 & 25766 & 28990 & 31313 & 29915 & 29511 & 28797 & 30982 & 28701 & 27599 \\
\hline \multirow{4}{*}{\begin{tabular}{c} 
Važecká Cave \\
\cline { 2 - 12 }
\end{tabular}} & June & 2286 & 2323 & 2216 & 2077 & 1838 & 2631 & 2525 & 2961 & 3082 & 2550 \\
\cline { 2 - 12 } & August & 3879 & 4709 & 3390 & 3423 & 4460 & 3824 & 5228 & 4414 & 4997 & 4705 \\
\hline
\end{tabular}

Data source: Slovak Caves Administration, Liptovský Mikuláš

The second most visited cave is the Demänovská Ice Cave. The total attendance for the three summer months in the period 2010-2019 reached 600510 visitors. The number of visitors reached the highest value from 20102019 in August (287 573), surpassing the Demänovská Cave of Liberty; the lowest attendance was traditionally in June ( 87 823). Most visitors came to the cave in 2017 when their number in 3 summer months reached 66,710, the least in 2011 (37 267).

The third most visited cave is the Bystrianska Cave. The total attendance in the cave for the three summer months in 2010-2019 reached 146569 visitors. The number of visitors reached the highest value in August (58 178), the lowest attendance was traditionally in June ( 35 686). Most visitors came to the cave in 2018 when their number in 3 summer months reached 17 982, the least in 2013 (12 180).

The least visited cave is Važecká Cave. The total attendance in the cave for the three summer months in 2010-2019 reached 112922 visitors. The number of visitors reached the highest value in August (45 403), the lowest attendance was traditionally in June (24 489). Most visitors came to the cave in 2018 when their number in 3 summer months reached 13 172, the least in 2012 (9 859).

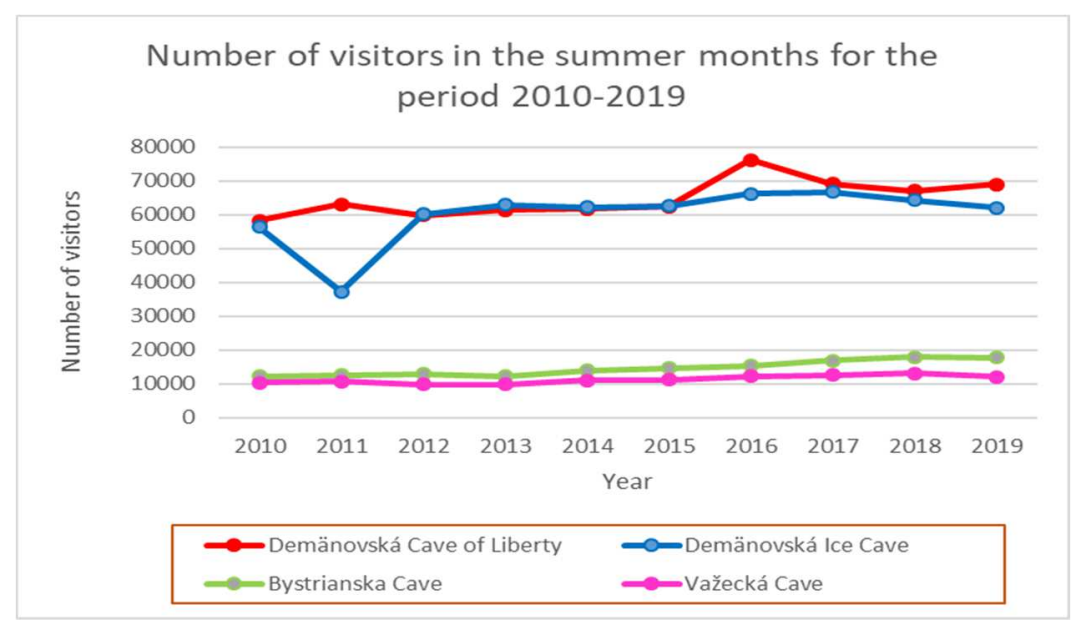

Fig. 2. Number of visitors in the summer months for the period 2010-2019 


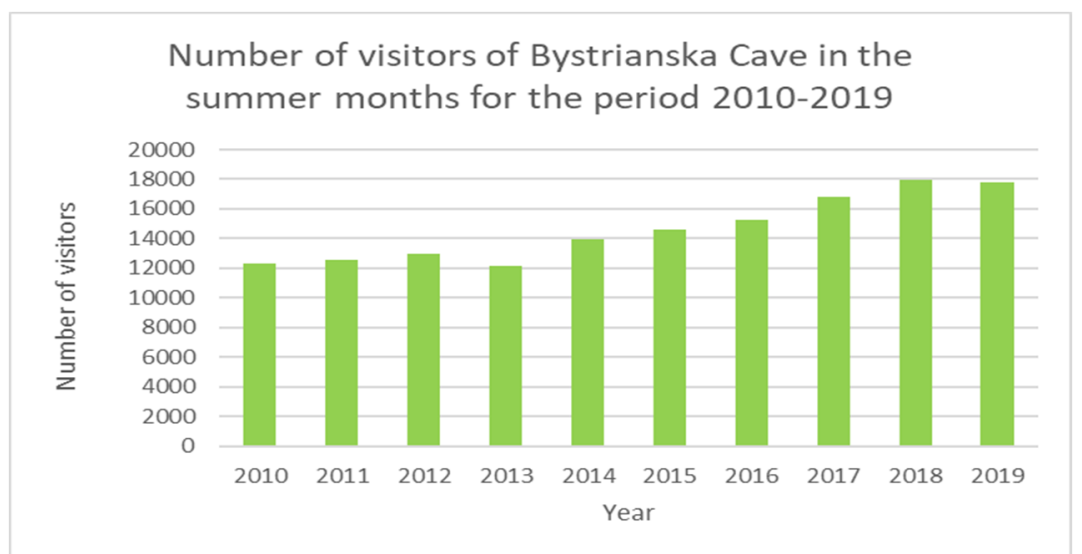

Fig. 3. Number of visitors of the Bystrianska Cave in the summer months for the period 2010-2019

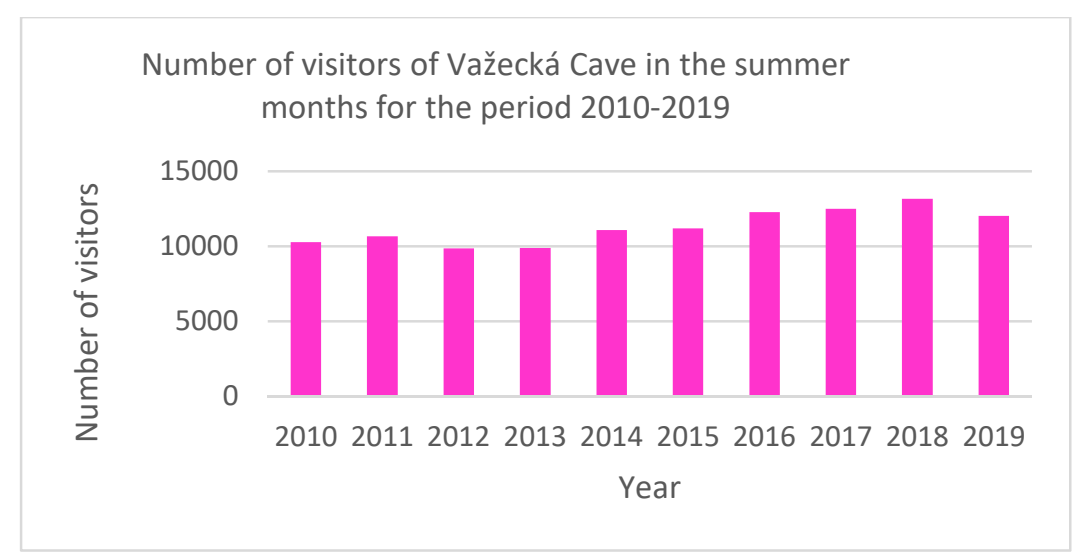

Fig. 4. Number of visitors of the Važecká Cave in the summer months for the period 2010-2019

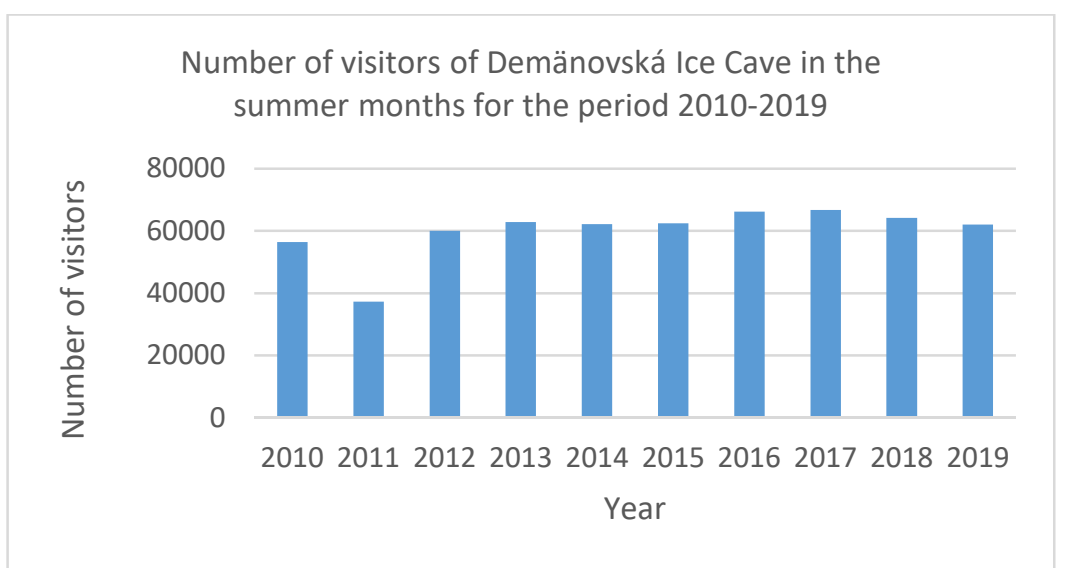

Fig. 5. Number of visitors of the Demänovská Ice Cave in the summer months for the period 2010-2019

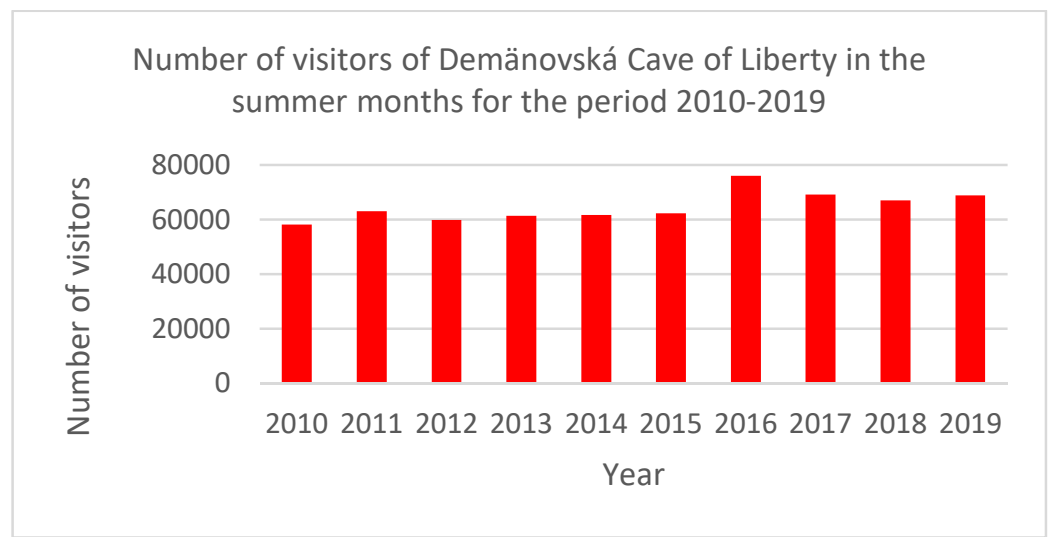

Fig. 6. Number of visitors of the Demänovská Cave of Liberty in the summer months for the period 2010-2019 
We selected 12 evaluation criteria (classification features) to analyze the potential of the investigated caves for speleotourism before conducting a public opinion survey. Respondents evaluated them to determine the significance of each criterion. The criterion of variety and attractiveness of the cave decoration and the guide's interpretation had the highest weight in the evaluation. These two criteria thus gained the highest significance. A group of three criteria consists of the following: the difficulty of the tour route, the occurrence of underground watercourses and lakes, and other tourist destinations in the cave's vicinity.

The third group of respondents included: accessibility from the parking lot to the cave entrance, the height of the entrance fee, lighting of the cave spaces, and safety on the tour route. According to the respondents, group 4 is less critical, consisting of only one criterion: transport accessibility concerning the main transport routes. The group with two criteria has the most negligible significance in terms of the cave's potential for speleotourism: information panels about the cave and its surroundings and services at the cave entrance.

From the point of view of public opinion survey evaluation, it can be stated that the Demänovská Cave of Liberty has the highest point value of speleotourism potential. It received the highest point rating out of all caves at classification features $1,4,5,8,11,12$. Respondents primarily positively assessed the rich occurrence of drip decoration along the entire tour route, the occurrence of watercourses and lakes at the tour route, the occurrence of other tourist destinations within a distance of $10 \mathrm{~km}$ from the cave, sufficient lighting, suitably complementing the tour of the cave, sufficient occurrence of information panels about the cave and the surrounding area and a good level of services at the entrance to the cave. On the contrary, the lowest point value of all four caves was given to the Demänovská Cave of Liberty for classification marks 3 and 6. Respondents pointed out the difficulty of the tour route in terms of elevation and number of stairs and the difficulty of the access route from the parking lot. The total value of the cave potential for speleotourism is 404,318 points. According to the respondents, the Važecká Cave has the second-highest potential for speleotourism. It received the highest point rating out of all caves for classification indices 2, 6, 7, 10 .

Respondents positively rated especially the excellent and funny interpretation of the guide with the possibility to ask questions, easy access from the parking lot to the cave entrance, the price of the entrance fee, commensurate with the experience gained, good transport accessibility concerning the main transport routes. On the contrary, the lowest point value of all four caves was given to Važecká Cave at the classification mark 12. Respondents pointed to average to insufficient services at the entrance to the cave. The total value of the cave potential for speleotourism is 395,487 points. The third in the order of evaluation of the potential of caves for speleotourism is the Bystrianska Cave. It received the highest point rating out of all caves for classification indices 3, 6, 9. Respondents positively assessed the undemanding tour route without significant elevations, undemanding accessibility from the parking lot to the cave entrance, sufficient safety on the tour route.

On the contrary, the lowest point value of all four caves was given to Bystrianska Cave at classification marks $2,4,5,8,10,11$. Respondents pointed out the average to the insufficient interpretation of the guide, absence of water flow and lakes on the tour route, the too distant occurrence of other tourist objectives from the cave, average to the poor lighting of some areas, more insufficient transport accessibility concerning the main traffic routes, the average to the insufficient occurrence of information panels about the cave and the surrounding area. The total value of the cave's potential for speleotourism is 322,652 points. The Demänovská Ice Cave has the lowest value of potential for speleotourism of the four evaluated caves. Within the classification features, it did not obtain the highest point rating for any classification feature. The lowest point value of all four caves was given to the Demänovská Ice Cave at classification marks 1, 7, 9. Respondents pointed out the low incidence of decoration, predominance of spaces without drip (or ice) decoration, entrance fee, inappropriate to the experience gained average to insufficient safety on the tour route. The total value of the cave's potential for speleotourism is 294,927 points.

Tab. 16. The summary point value for individual classification indices and the resulting potential value (K) for speleotourism

\begin{tabular}{|c|c|c|c|c|c|}
\hline $\begin{array}{c}\text { Classification } \\
\text { index }\end{array}$ & $\begin{array}{c}\text { Classification } \\
\text { index }\end{array}$ & $\begin{array}{c}\text { Bystrianska } \\
\text { Cave }\end{array}$ & $\begin{array}{c}\text { Demänovská } \\
\text { Cave of Liberty }\end{array}$ & $\begin{array}{c}\text { Demänovská } \\
\text { Ice Cave }\end{array}$ & $\begin{array}{c}\text { Važecká } \\
\text { Cave }\end{array}$ \\
\hline 1 & $k_{1 i}$ & 35,584 & 59,776 & 16,896 & 50,56 \\
\hline 2 & $k_{2 i}$ & 38,628 & 70,656 & 43,08 & 71,04 \\
\hline 3 & $k_{3 i}$ & 52,281 & 22,422 & 26,862 & 43,179 \\
\hline 4 & $k_{4 i}$ & 18,204 & 53,28 & 18,759 & 34,077 \\
\hline 5 & $k_{5 i}$ & 23,088 & 49,728 & 48,729 & 25,197 \\
\hline 6 & $k_{6 i}$ & 39,84 & 16,517 & 17,43 & 39,84 \\
\hline 7 & $k_{7 i}$ & 18,924 & 20,667 & 17,762 & 22,161 \\
\hline
\end{tabular}




\begin{tabular}{|c|c|c|c|c|c|}
\hline 8 & $k_{8 i}$ & 33,615 & 38,014 & 35,856 & 36,686 \\
\hline 9 & $k_{9 i}$ & 39,176 & 38,346 & 36,105 & 38,263 \\
\hline 10 & $k_{10 i}$ & 9,608 & 19,272 & 18,964 & 20,68 \\
\hline 11 & $k_{11 i}$ & 6,392 & 7,939 & 7,616 & 7,344 \\
\hline 12 & $k_{12 i}$ & 7,412 & 7,701 & 6,868 & 6,46 \\
\hline $\mathbf{K}$ & $\mathbf{K}$ & 322,652 & 404,318 & 294,927 & 395,487 \\
\hline
\end{tabular}

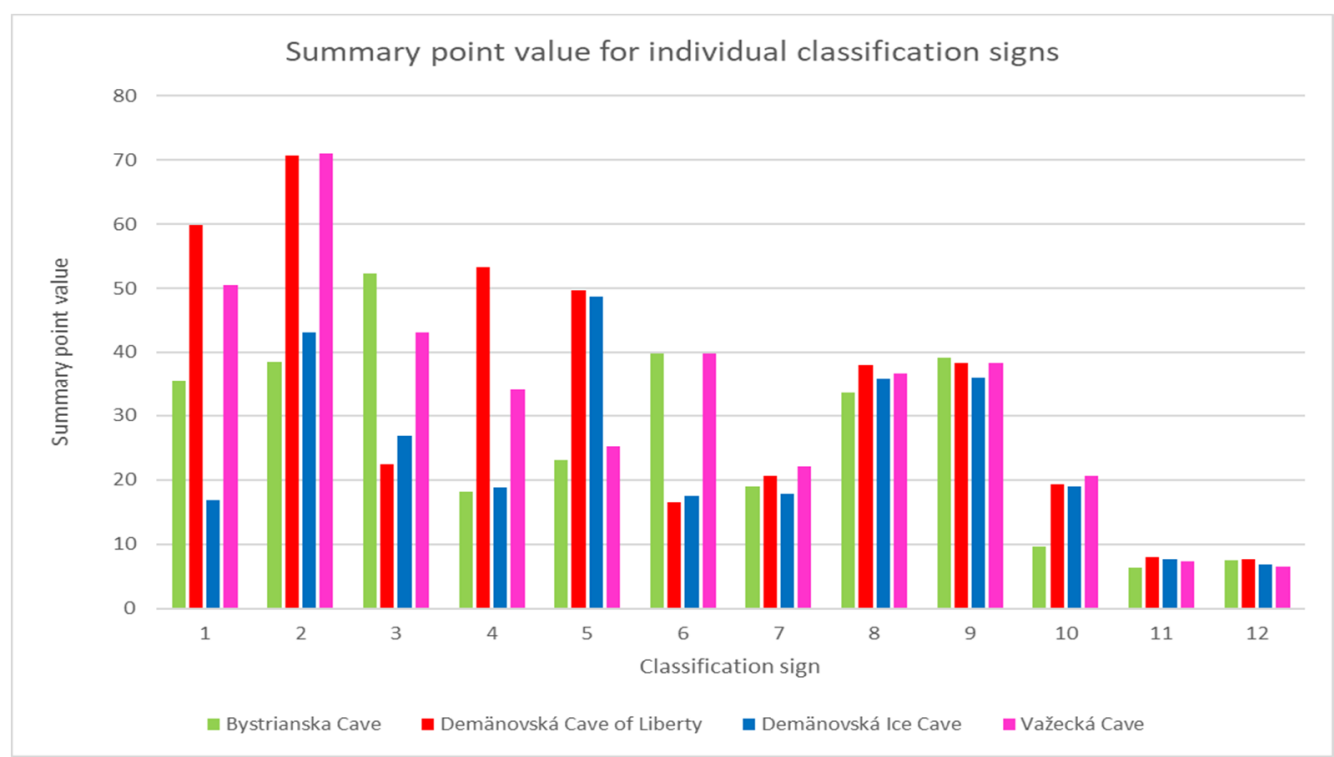

Fig. 7. Summary point value for individual classification indices

\section{Discussion}

Based on the results of the caves attendance and the public opinion survey, it can be stated that the first hypothesis was not confirmed. The assumption of a continuous increase in caves attendance was not confirmed due to the identified data on the annual increase in the number of visitors in the Low Tatras National Park. The Demänovská Cave of Liberty had the peak of attendance in 2016, as did the Demänovská Ice Cave (2017). In the second named cave, the relatively harsh winter of 2016/2017 has a significant impact on this fact, which has created suitable conditions for glaciation of underground spaces. The low number of visitors to the Demänovská Ice Cave in 2011 was caused by reconstruction work during almost the entire month of July when the cave was closed. Bystrianska Cave recorded the continuous annual growth of attendance from 2013 to 2018; in 2019, there was a slight decrease. Similarly, the Važecká Cave recorded a continuous annual increase in attendance from 2012 to 2018 ; in 2019, there was also a slight decrease.

The second hypothesis was confirmed. In absolute numbers, most visitors visited the Demänovská Cave of Liberty and the Demänovská Ice Cave in the summer months, due to the intense onslaught of tourism in the Demänovská Valley. These caves are well promoted in marketing and advertising. The advantage of the Demänovská Ice Cave is its location, as it lies closer to the entrance to the valley than the Demänovská Cave of Liberty. Many tourists (who do not have a general idea of the character of the Demänovské Caves) will stop in the parking lot of this cave, and in case of lack of time, they will not even get further into the valley to the parking lot under the Demänovská Cave of Liberty. The disadvantage of the Demänovská Ice Cave compared to the Demänovská Cave of Liberty is the low proportion of dripstone decoration. The ice fill in the Demänovská Ice Cave is decreasing due to the global temperatures increase and mild winter predominance; therefore, the ice decoration is at a minimum in the summer months except for 2017. Due to global warming, the cave has reached the minimum of ice filling approximately in the last 70 years. Only in the central part - the heart of the cave is there still ice, but only in the form of floor ice. There are no vertical forms of ice filling in the cave in the summer, so they can only be admired in the photographs. Therefore, visitors' experiences and impressions are embarrassing regarding the expectation of the ice fill amount.

The third hypothesis was also confirmed. Važecká Cave has the lowest number of visitors, primarily due to its marginal location concerning the main centers of tourism in the Low Tatras (South and North Chopok). The 
cave has good transport accessibility (close connection to the D1 motorway, easy access to the cave, and a leisurely tour route. Due to the size of the cave, the tour route is short (only $25 \mathrm{~min}$ ), services at the entrance to the cave are weaker than the other three caves, the parking lot requires reconstruction.

The fourth hypothesis was confirmed. Guide's approach and interpretation are essential in evaluating the cave in terms of its attractiveness, respectively, the potential for speleotourism. Respondents gave this classification feature, together with the diversity of cave decoration, the highest weight in assessing the potential for speleotourism. In this respect, the highest rating was given to the Važecká Cave, with the Demänovská Cave of Liberty just behind. Bystrianska Cave received the lowest rating. Respondents are particularly optimistic about the possibility of asking questions and the relaxed humorous interpretation of the guide.

The fifth hypothesis was also confirmed. Demänovská Cave of Liberty has the highest potential for speleotourism, even according to the respondents, primarily due to the character of underground spaces with a lot of varied cave decoration. This potential exceeds the borders of Slovakia, therefore even among foreign visitors, the cave, together with the Belianska Cave, is the most visited. Visitors also appreciate the option of choosing two types of sightseeing tours (traditional and long circuit), although the price of an extended circuit is considered exaggerated by some visitors.

\section{Conclusion}

Publicly accessible caves of the Low Tatras National Park and the surrounding area, managed by the Slovak Caves Administration, represent significant geolocations with an accumulation of visitors in this area. They allow visitors to look into the mysterious underground world and provide pleasant cooling on hot summer days. The paper presents an analysis of attendance over the last decade and a public opinion survey to assess the potential for speleotourism. Such an analysis has not yet been carried out in the geographical area of the Slovak Republic. In the future, it is possible to follow up on this research by expanding the analysis on all publicly accessible caves in Slovakia.

The results of our research determined that the most attractive geolocality for visitors in terms of (underground) speleotourism is the Demänovská Cave of Freedom, when it is more attractive than the specific geolocality Demänovská Ice Cave. This cave seems less attractive for visitors because in the period of warmer winters, not enough ice decoration is created in the underground spaces, and karst decoration is also absent in the cave. For this reason, underground spaces are relatively austere, and logically less attractive. Based on these conclusions and ongoing research into the attractiveness of caves in terms of speleotourism in Slovakia, we predict that the Dobšinská Ice Cave and the specific Ochtinská Aragonite Cave will dominate among caves as significant geolocalities in terms of attractiveness for visitors.

For (underground) speleotourism, i.e. visit to caves in Slovakia in the mountains of the Western Carpathians, the most important factor is its sustainability. Sustainability of cave attendance in Slovakia is ensured in the future by the fact that all 13 accessible caves in Slovakia are within the competence of the state institution Slovak Cave Administration based in Liptovský Mikuláš as an organizational unit of the State Nature Conservancy of the Slovak Republic in the Ministry of the Environment of the Slovak Republic. Therefore, even in the case of a bad economic situation, when the cave will not be able to earn money for its operation, it will continue to be subsidized and operated (https://www.ssj.sk/sk). Caves within the scope of the Slovak Cave Administration, as invaluable and irreplaceable geolocalities of world importance, require special protection, care and presentation. At present, all caves in Slovakia are protected as national natural monuments. For this reason, up to five caves have been included in the UNESCO World Natural Heritage List (Ochtinská Aragonite Cave, Domica Cave, Gombasecká Cave, Jasovská Cave and Dobšinská Ice Cave). Therefore, from the point of view of the sustainability of speleotourism and underground protection, it is important to monitor the impact of visitors on the natural environment of caves and to actively manage and guide it. 


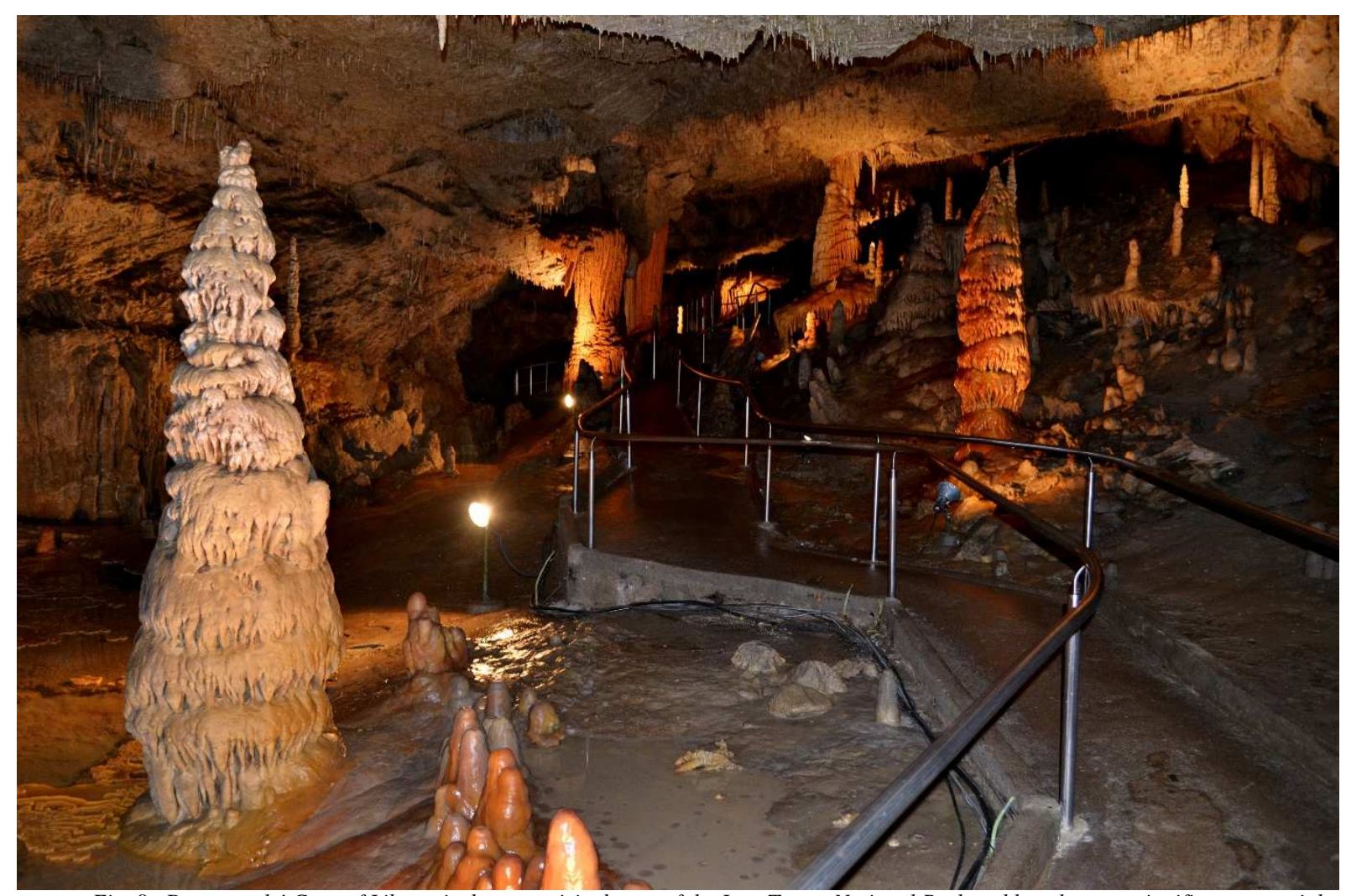

Fig. 8. Demänovská Cave of Liberty is the most visited cave of the Low Tatras National Park and has the most significant potential for speleotourism based on a public opinion survey. Photo: V. Cech

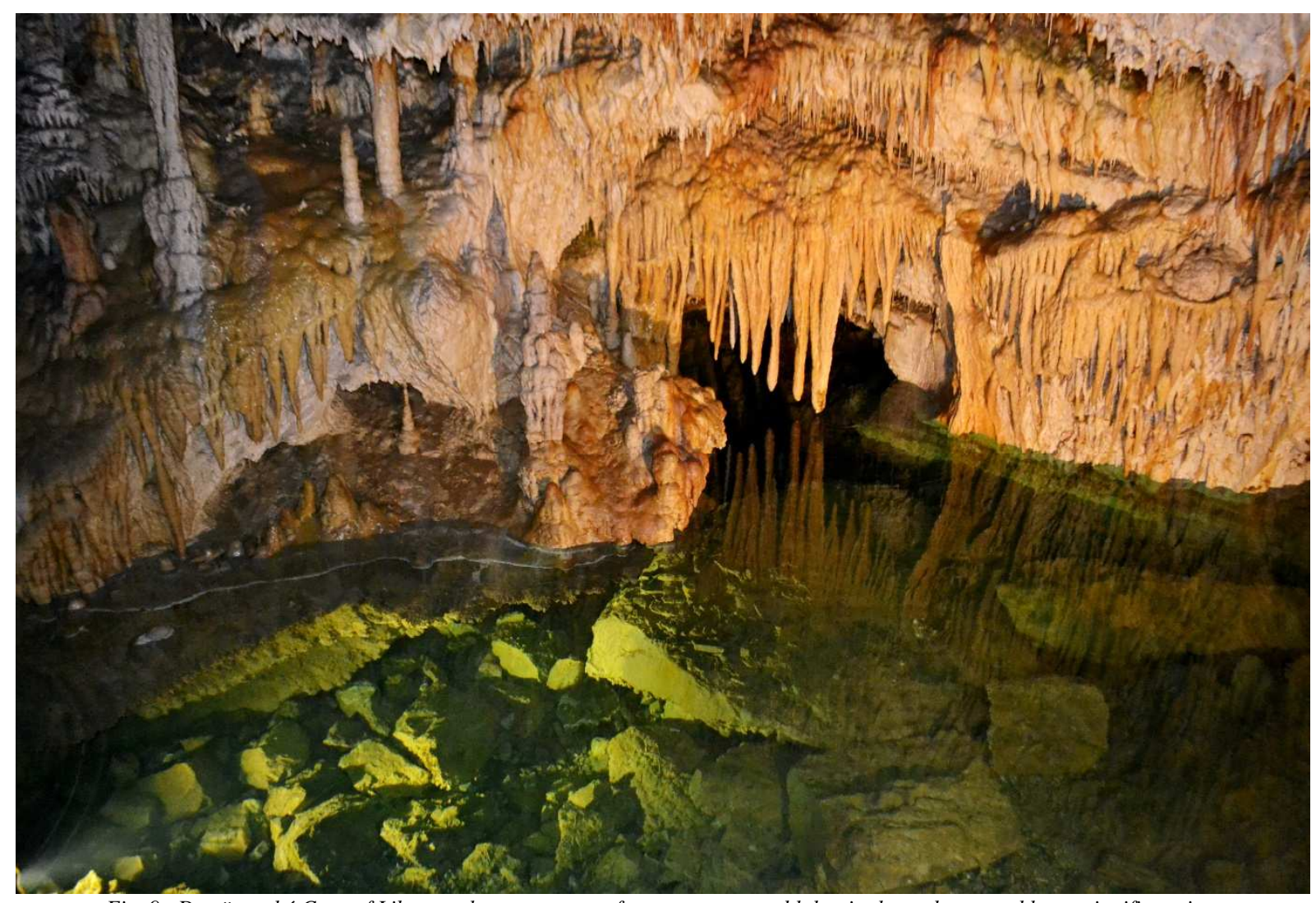

Fig. 9. Demänovská Cave of Liberty - the occurrence of watercourses and lakes in the underground has a significant impact on increasing the value of the potential for speleotourism. Photo: V. Čech 


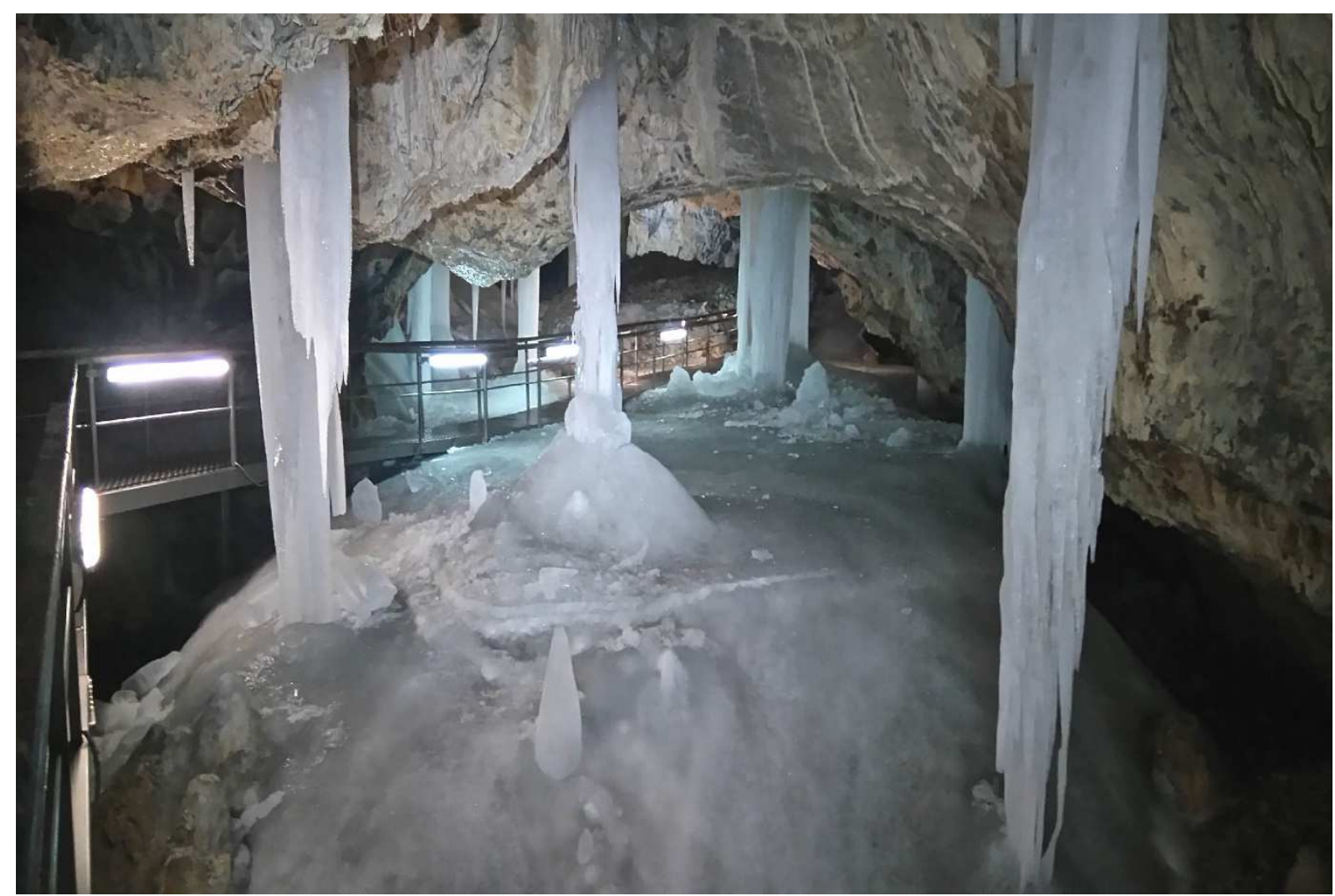

Fig. 10. Demänovská Ice Cave - such vertical ice decoration can currently be admired only in photographs in the summer months due to global warming. Photo: V. Čech (2017)

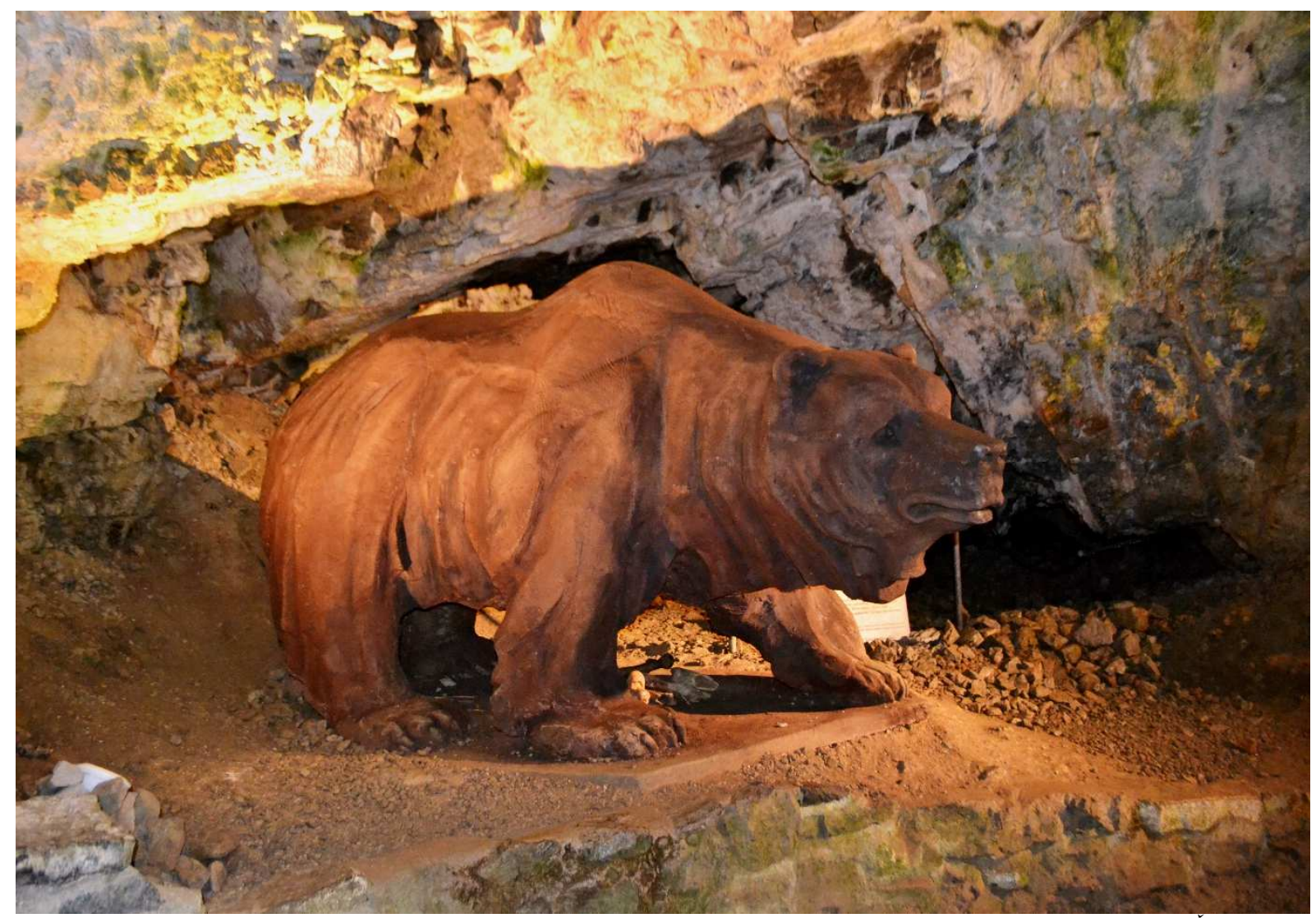

Fig. 11. A life-size sculpture of a cave bear (Ursus spelaeus) behind the entrance to the Važecká Cave. Photo: V. Čech 


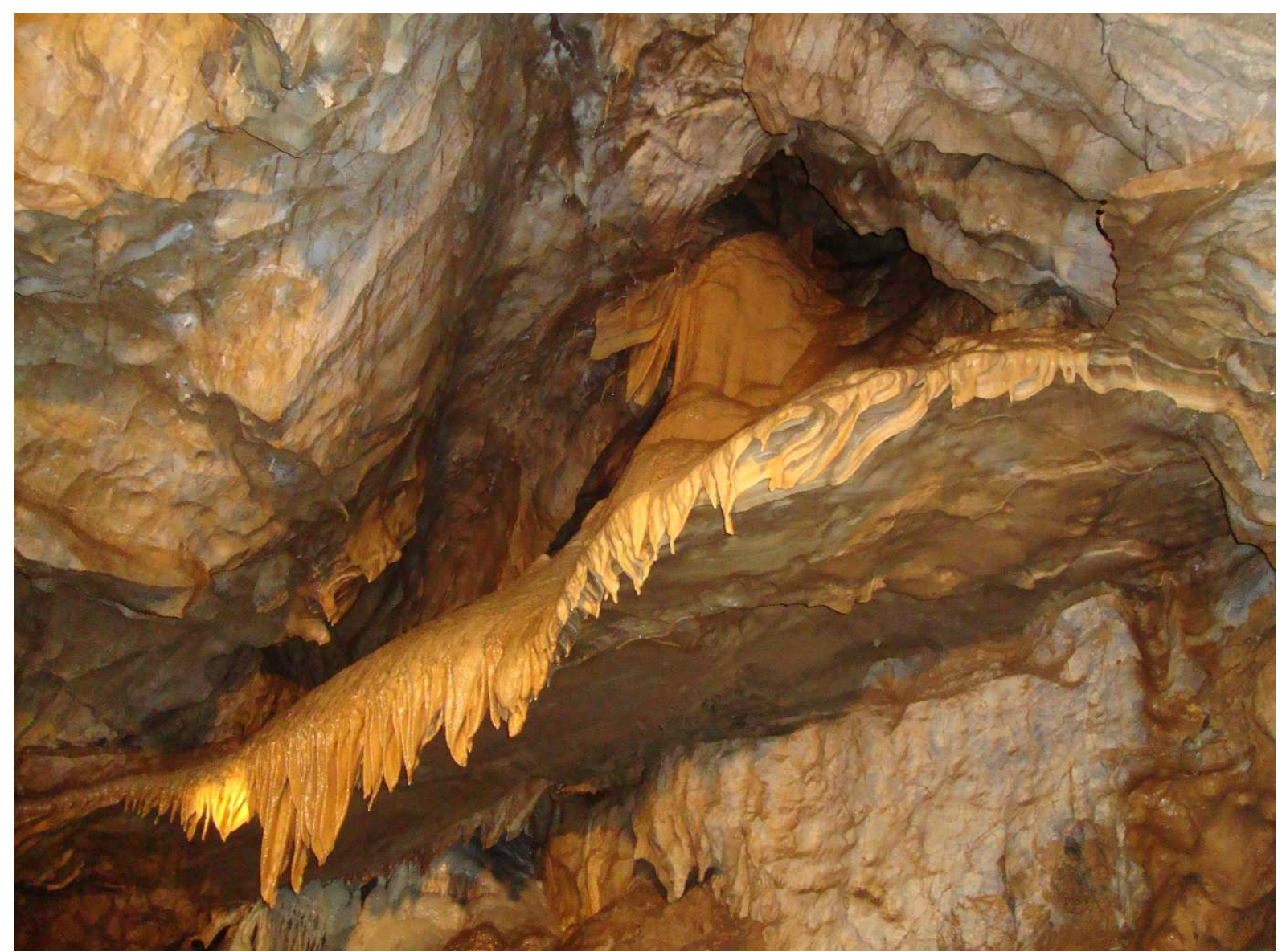

Fig. 12. „Baldachýn” symbol of the Bystrianska Cave. Photo: B. Gregorová

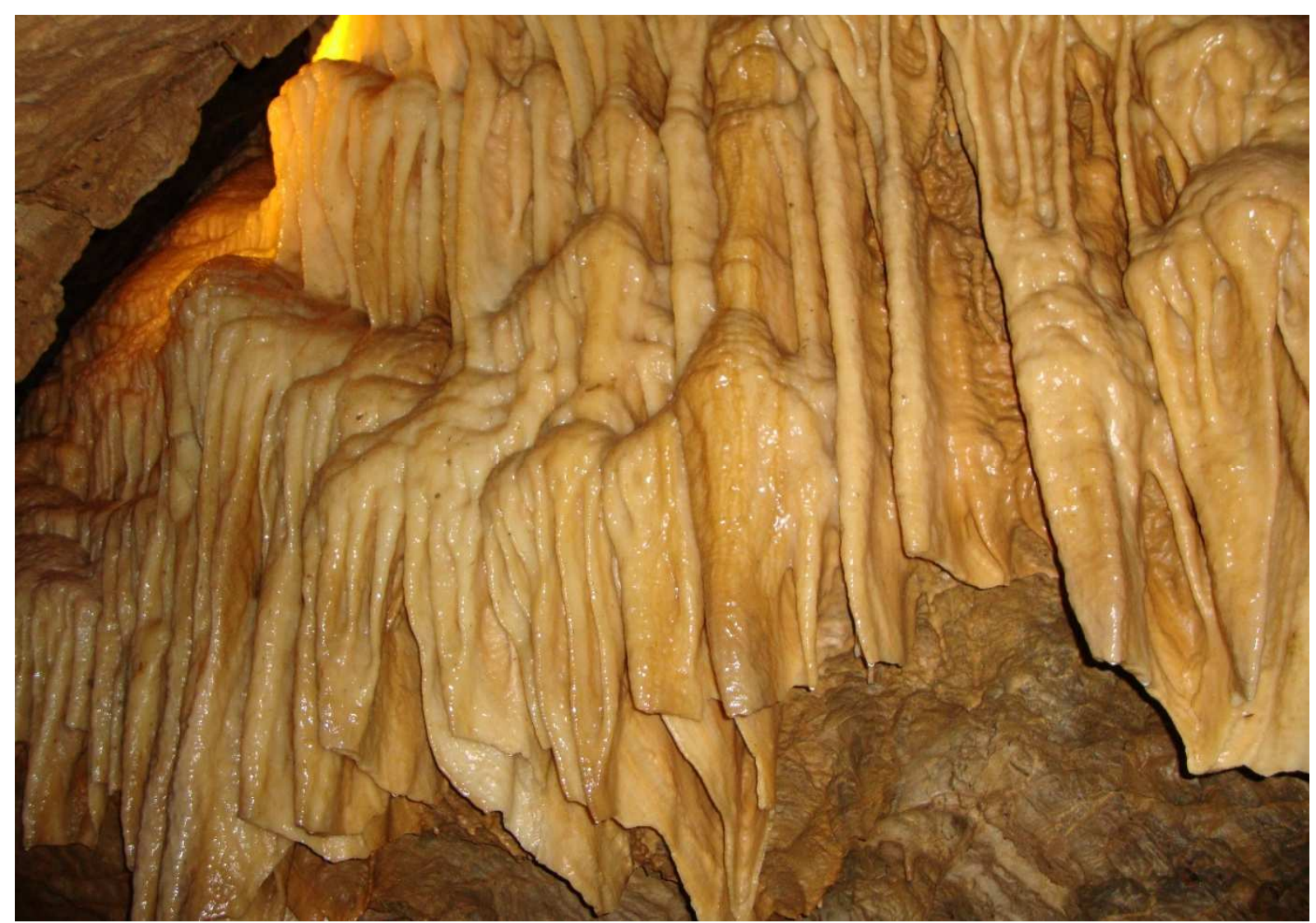

Fig. 13. Sinter decoration of the Bystrianska Cave. Photo: B. Gregorová 


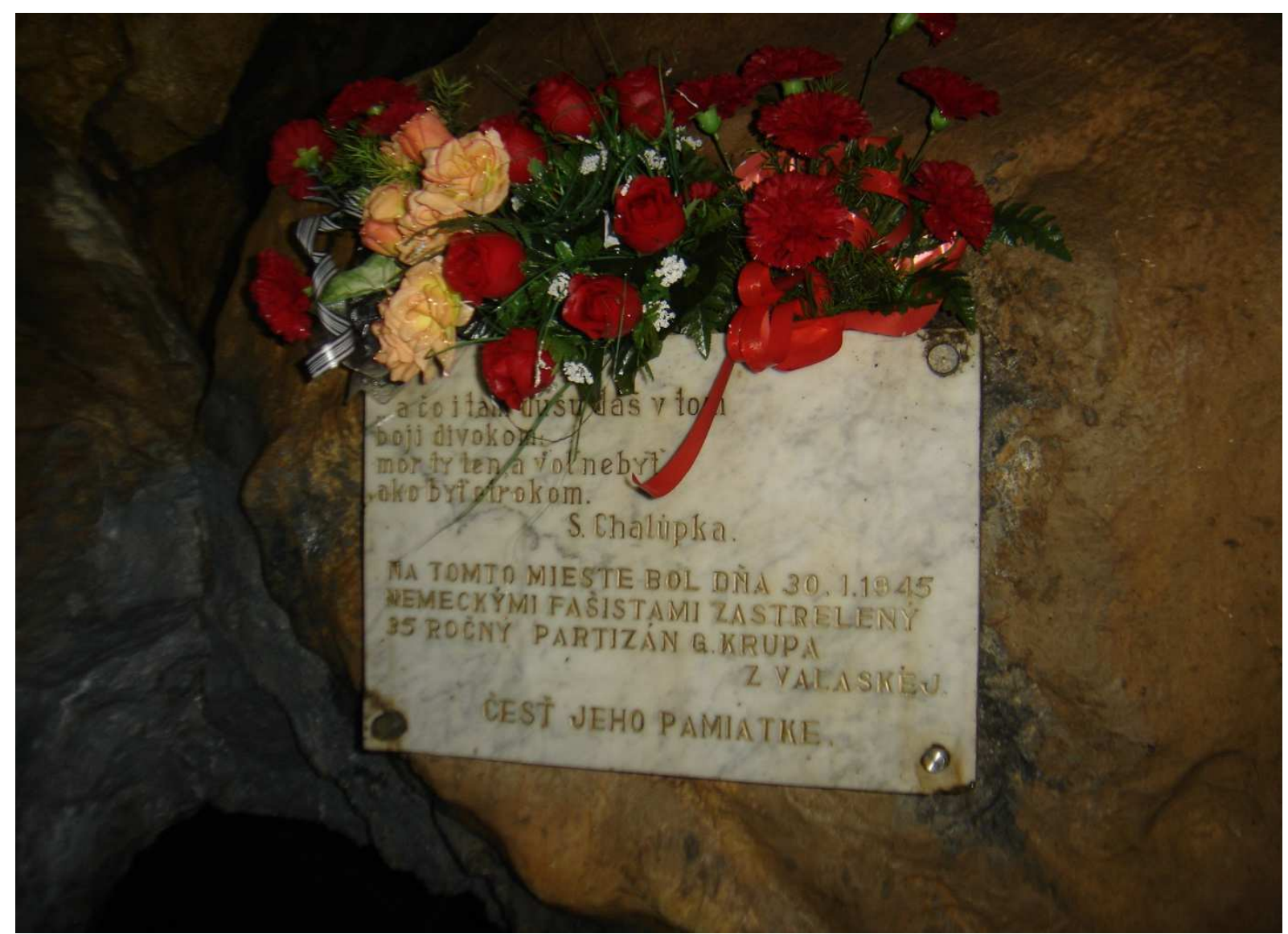

Fig. 14. Bystrianska Cave played a significant role during World War II, as pointed out by this memorial plaque. Photo: V. Čech

\section{References}

Act No. 543/2002 Coll. (Zákon č. 543/2002 Z. z.): Nature and Landscape Protection Act (Zákon o ochrane prírody a krajiny).

Anderson, J.: Caves and karst geotourism in Australia. In: Dowling, R. and Newsome, D. (Eds.): Global Geotourism Perspectives, Oxford: Goodfellow Publishers Ltd., pp. 49-69, 2010.

Antić, A.: Speleotourism potential and tourist experience in Resava cave. In: Hotel and Tourism Management, 6 (2), pp. 61-69, 2018.

Antić, A. and Tomić, N.: Assessing the speleotourism potential together with archaeological and palaeontological heritage in Risovača cave (central Serbia). In: Acta Geoturistica, 10 (1), pp. 1-11, 2019.

Bella, P.: Fluviálna modelácia Bystrianskej jaskyne. Výskum, využívanie a ochrana jaskýň, zborník referátov, Liptovský Mikuláš 36-43, 1998.

Bella, P.: Jaskyne. Prírodné krásy Slovenska. Dajama, 120 p, 2011.

Bella, P. et al.: Jaskyne Demänovskej doliny. AEPress, s.r.o., Bratislava (Vydala Štátna ochrana prírody SR), 2014.

Cardozo Moreira, J. and Neto de Carvalho, C.: Worldwide speleotourism: approaches for economic and heritage sustainability. In: Tourism and Karst Areas, 6 (1), pp. 4-8, 2013.

Cigna, A. A.: Environmental management of tourist caves: the examples of Grotta di Castellana and Grotta Grande del Vento, Italy. In: Environmental Geology, 21, pp. 173-180, 1993.

Cigna A. A. and Burri E.: Development, management and economy of show caves. In: International Journal of Speleology, 29 B (1/4), pp. 1-27, 2000.

Cigna A. A. and Forti P.: Caves: the most important geotouristic feature in the world. In: Tourism and Karst Areas, $6(1), p p .9-26,2013$.

Doorne, S.: Caves, culture and crowds: carrying capacity meets consumer sovereignty. In: Journal of Sustainable Tourism, 8(2), pp. 116-130, 2000.

Droppa, A.: Demänovské jaskyne. Krasové zjavy Demänovskej doliny. SAV, Bratislava, 289 p, 1957a.

Droppa, A.: Speleologické problémy Bystrianskej jaskyne. Krásy Slovenska, 34, 2, 75-78, $1957 b$.

Droppa, A.: Demänovské jaskyne a zaujímavosti krasu v okolí. Šport, Bratislava, 160 p, 1959. 
Droppa, A.: Važecká jaskyňa a krasové javy v okolí. Šport, Bratislava, 96 p, $1962 a$.

Droppa, A.: Speleologický výskum Važeckého krasu. Geografický časopis, 14, 4, 264-293, 1962 b.

Droppa, A.: Geomorfologické pomery Demänovskej doliny. Slovenský kras, 10, 9-46, 1972.

Emeka, E. O., Ezekaka, A. and Igwemadu, M.: Cave Tourism and its Implications to Tourism Development in Nigeria: A Case Study of Agu-Owuru Cave in Ezeagu. In: International Journal of Research in Tourism and Hospitality (IJRTH), 3 (3), pp. 16-24, 2017.

Figueiredo, L. A. V.: Cavernas brasileiras e seu potencial ecoturístico: Um panorama entre a escuridão e as luzes. In: Vasconcelos, F.P. (org.) Turismo e meio ambiente. UECE, Fortaleza, pp. 1-22, 1998.

Forti, P. and Cigna, A. A.: Cave tourism in Italy: an overview. In: Kranjc, A. and Kranjc, M. (Eds.): Cave tourism. Proceedings of International Symposium at 170-anniversary of Postojnska jama. Postojna, pp. 46-53, 1989.

Hochmuth, Z.: Krasové územia a jaskyne Slovenska. Geographia Cassoviensis, vol. II, nr. 2, Košice, Univerzita Pavla Jozefa Šafárika. 210 p, 2008.

Knežević, R. and Grbac-Žiković, R.: Analysis of the condition and development opportunities of cave tourism in Primorsko-Goranska County. In: Turizam, 15 (1), pp. 11-25, 2011.

Kranjc A.: Zgodovina jamskega turizma. In: Luthar, O., Dobrovoljc, H., Fridl, J., Mulec, J., Pavšek, M. (Eds.): Kras: trajnostni razvoj kraške pokrajine. Založba ZRC, Ljubljana, pp. 281-286, 2008.

Lobo, H. A. S.: Método para avaliação do potencial espeleoturístico do Parque Nacional da Serra da Bodoquena, MS. In: Caderno Virtual de Turismo, 7 (3), pp. 99-110, 2007.

Lobo, H.A.S. and Moretti, E. C.: Tourism in Caves and the Conservation of the Speleological Heritage: The Case of Serra da Bodoquena (Mato Grosso do Sul State, Brazil). In: Acta Carsologica, 38, pp. 265-276, 2009.

Panoš, V.: Karsologická a speleologická terminologie. Knižné centrum, 352 p, 2001.

Pavlovich K.: The evolution and transformation of a tourism destination network: the Waitomo Caves, New Zealand. In: Tourism Management, 24, pp. 203-216, 2003.

Ruban, D. A.: Karst as Important Resource for Geopark-Based Tourism: Current State and Biases. In: Resources, 7 (82), pp. 1-8, 2018.

Ríha, J.: Hodnocení vlivu investic na životní prostředí. Vícekriteriální analýza a EIA. Nakladatelství ACADEMIA Praha, 348 p, 1995a.

Ř́ha, J.: Objektivizace vah kritérií v procesu EIA. Stavební obzor, 1, pp. 22-26, 1995 b.

Švec, Š.: Metodológia vied o výchove: Kvantitatívno-scientické a kvalitatívno-humanitné prístupy v edukačnom výskume. Iris Bratislava, 1998.

Taylor-Powell, E.: Questionnaire Deindex: Asking questions with a purpose. University of Wisconsin Extension, 1998.

Tičar, J., Tomić, N., Valjavec, M. B., Zorn, M., Marković, S.B. and Gavrilov, M. B.: Speleotourism in Slovenia: balancing between mass tourism and geoheritage protection. In: Open Geosciences, 10, pp. 344-357, 2018.

Tomić, N., Antić, A., Marković, S. B., Dordević, T., Zorn, M., and Valjavec, M. B.: Exploring the Potential for Speleotourism Development in Eastern Serbia. In: Geoheritage, pp. 1-11, 2018.

Ulloa, A. and Goicoechea, C.: Geotourism potential of underground sites in Costa Rica. Tourism and Karst Areas. 6. 43-56, 2013.

Vuković, S. and Antic, A.: Speleological Approach for Geotourism Development in Zlatibor County (West Serbia). Turizam, 23 (1), 53-68, 2019.

Zelenka, J. and Pásková, M.: Cestovní ruch. Výkladový slovník. Praha: Linde, 768 p, 2012. 